\title{
Az optimális valutaövezet két elmélete - aszimmetrikus sokkok és nemzetközi pénzügyi integráció
}

Robert Mundell híres 1961. évi cikkét tekintik az optimális valutaövezetek elmélete első megalapozásának. Valójában azonban az a cikk nem egy, hanem két elméletet alapozott meg. Az első az, amelyről a közgazdászok általában beszélnek. Ez az elmélet inkább a negatív ítélet felé hajlik. Ne vállaljunk közös valutát olyan országokkal, amelyek gazdaságának kibocsátási szerkezete eltér a miénktől, mert olyan negatív keresleti sokk sújthat bennünket, amely őket nem érinti, és bajba kerülünk, ha a közös valutával megfosztjuk magunkat a leértékelés lehetőségétől. És más hasonló érvek - ez az 1. elmélet. Mundell cikke azonban arról is szól néhány, az irodalomban sohasem idézett mondatban, hogy a nem rögzített árfolyam súlyos bajok forrása lesz akkor, ha a nemzetközi tőkemozgásokat liberalizálják. A később valósággá vált liberalizálás jelentős nemzetközi integrációs tendenciákat váltott ki a pénz- és tőkepiacokon, amelyek különös erővel érvényesültek az Európai Közösségek, később az Európai Unió gazdasági-politikai együttmüködési-szövetségi rendszerén belül. Ezzel a Mundell által elörevetített probléma valósággá vált. Ehhez sok más közgazdász által írt újabb, fontos írások kapcsolódtak. Ezekböl összerakható egy másik optimális valutaövezeti elmélet: ez a 2. elmélet. Ez pozitívabb: inkább a monetáris integráció mellett szól, és erősen ösztönözte is az euró megteremtését. * Journal of Economic Literature (JEL) kód: B27, B31, E42, F02, F33, F45, G15.

\section{Bevezetés}

Ha egy magyar közgazdász az optimális valutaövezet problémái iránt érdeklödik, akkor alapjában véve nyilván az euróövezethez való magyar csatlakozás lehetősége, szükségessége, feltételei foglalkoztatják. Így van ez ebben az esetben is. Ez a cikk azonban befejeződik anélkül, hogy magát a konkrét magyar eurókérdést feltenné. Ugyanis bőven elegendő tisztáznivalót ad maga az általánosabb probléma: az, hogy általában milyen

* Az írás korábbi változatához tett megjegyzéseikért, javaslataikért köszönettel tartozom Halpern Lászlónak, Oblath Gábornak és Surányi Györgynek. Minden megmaradt hibáért engem terhel a felelősség.

Soós Károly Attila, KRTK KTI (e-mail: soos.karoly.attila@krtk.hu). A kézirat első változata 2021. szeptember 6-án érkezett szerkesztőségünkbe. DOI: https://doi.org/10.18414/KSZ.2021.12.1250 
kérdéseket tegyünk fel akkor, amikor el kell dönteni azt, hogy csatlakozzunk-e egy monetáris unióhoz - egy EU-tagország estében az euróövezethez. Természetesen az optimális valutaövezet elméletéből kell kiindulni. Csakhogy ilyen elméletből valójában nem egy van, hanem kettö, ami természetesen bonyodalmakat okoz.

Ugyanakkor egyszerüsíti a feladatunkat az, hogy az elméletek története rövid, mert rövid magának a problémának a tulajdonképpeni története. Igaz, közgazdászok már nagyon régen felvetették a világ sokféle pénzének problémáját, de nagyon másképp gondolkoztak róla, mint ahogy újabban szoktunk. Például az ismert 19. századi közgazdász, John Stuart Mill „barbárságnak” nevezte azt, hogy

„majdnem minden független állam azzal bizonygatja ország mivoltát, hogy önmaga és szomszédjai kárára külön saját valutát tart fenn" (Mill [1894] 176. o.).

Ennek kapcsán Robert Mundell megjegyezte, hogy Millt másokhoz (például Walter Bagehothoz) hasonlóan akkortájt - a nemzeti valuták burjánzása idején - csak a valutaváltási költségek miatt foglalkoztatta a probléma (Mundell [1961] 662. o.). Tehát akkor még nem azt a jóval bonyolultabb kérdést boncolgatták, hogy a sok valuta könnyíti-e vagy inkább nehezíti a munkanélküliség és a folyó fizetési mérleg hiányának/többletének korlátok között tartását (Mundell itt a „stabilizáció” szót használta). Így aztán a régi idők valutaárfolyam-vitái - amennyire egyáltalán voltak ilyenek a mi szempontunkból nem igazán érdekesek. Azok a viták, amelyekből tanulhatunk, a múlt század közepén robbantak ki.

Az első világháborúval megindult az aranyalapú, azaz rögzített árfolyamú (bár az összes akkori országra sohasem kiterjedő) pénzrendszer megszünése. A háború finanszírozási igényeit követő papírpénz-kibocsátás miatt a legtöbb kormány felfüggesztette a pénz aranyra válthatóságát. A háború után számos nagyobb és kisebb országban több-kevesebb kitartással próbálkoztak az aranyalapú pénz viszszaállításával. Ez egyrészt azért nem vezetett (tartós) eredményre, mert megszünt és nem állt helyre a nemzetközi együttmüködésnek az a komplex rendszere, amely az aranyalapú pénzek uralmának alapja (vagy komplementere) volt (Polányi [2004]). Másrészt a gyári munkásság létszámának jelentős megnövekedésével, az általános szavazati jog és a szociáldemokrata pártok kialakulásával a kormányok számára a munkanélküliség elleni fellépést lehetővé tevő „szabad” pénzteremtés fokozatosan fontosabb lett a pénzük aranyalapjánál. ${ }^{1}$ Ennek és részben más tényezőknek a hatása miatt az aranyra válthatóság fenntartására, visszaállítására irányuló kísérletek elbuktak, és terjedni kezdtek az egyoldalú kereskedelmi előnyök szerzését célzó, egymással versengő valutaleértékelések.

A második világháború után ezt a rendszert egy jobbal akarták felváltani. Az 1946. évi Bretton Woods-i konferencia döntései alapján az aranyalapú dollárhoz rögzítették a többi valuta árfolyamát ( \pm 1 százalékos kilengéssel). Emellett megengedték (és a kormányok kiterjedten alkalmazták is) a nemzetközi tőkemozgások korlátozását. Egyensúlyi zavarok esetén az árfolyamok kiigazítása is meg volt engedve; ezt a keynesiánus

\footnotetext{
${ }^{1}$ Erröl írt Friedman [1953a] 179. o.
} 
ihletésű szabályt bizonyára akkor is törvénybe iktatták volna, ha maga Keynes nem lett volna a tárgyalások kulcsfontosságú szereplöje.

Ezzel azonban a versenyző leértékelések veszélyét is visszahozták; ez a hozzá kapcsolódó inflációs rohamokkal a rendszer szétzilálásához vezethetett volna. Emiatt 1950-től lényegében rögzített árfolyamrendszert kezdtek alkalmazni, nagyon kevés leértékelést engedve. Amivel - részben a termelékenységnövekedés, részben az infláció országok közötti különbségei miatt, de persze a tőkemozgások kontrollálásának nehézségeiből fakadóan is - egyes országokban jelentős folyófizetésimérleg-hiány, más országokban többletek kezdtek megjelenni, és gyakran egészen abszurd eszközökkel próbálták ezeket visszaszorítani. Alkalmaztak például vámokat helyettesítő „határadókat” (amelyek formálisan nem sértették a vámcsökkentési megállapodásokat), és az Egyesült Államokban a külföldre utazó turistákra is ki akartak vetni adót, bár ezt a Kongresszus nem szavazta meg (Haberler [2015] 120. o.).

Így aztán adottak voltak a feltételek az árfolyamrendszerekröl szóló nagy közgazdászviták kialakulásához. A viták során (lásd az alábbi első két fejezetet) az 1970es évek elejére lényegében kialakult az optimális valutaövezet elmélete (annak első elmélete), noha a továbbiakban (lásd az alábbi harmadik fejezetet) kiegészült még az endogenitás elemzéseivel: annak felismerésével, hogy az egyszer létrejött monetáris unióban müködnek olyan erők, amelyek fokozzák az addig nem vagy csak kevéssé teljesült optimalitási feltételek teljesülését. Ugyanakkor az is kiderült, hogy az ilyen endogén fejlődésnek korlátai vannak.

A viták az 1970-es évek elejétől elcsöndesedtek, és csak közel két évtizeddel később élénkültek ismét, amikor kezdett konkrét formát ölteni a közös EU-pénz megteremtésének terve. Akkorra a pénz-és tőkepiacok nemzetközi összefonódása - a pénzügyi integráció - olyan körülményeket teremtett, amelyek új fényt vetettek a monetáris integráció problémájára. Így megjelentek olyan elemzések, amelyek nézetem szerint összességükben az optimális valutaövezet addigi elméletét egy másikkal egészítették ki (lásd az alábbi negyedik fejezetet). A cikk utolsó fejezete az összefoglalást és a következtetéseket tartalmazza.

\section{Milton Friedman és Robert Mundell}

A Bretton Woods-i rendszer (a lényegében rögzítettárfolyam-rendszer) idején a vitatkozók többsége, nem meglepő módon, a rugalmas (lebegő) árfolyam mellett foglalt állást.

A viták egyik fontos résztvevője Milton Friedman volt, akit elsősorban a szabadon lebegtetett valutaárfolyam híveként ismerünk. Friedman [1953b] szerint mivel a valóságban az árak és a bérek „ragadósak”, a rájuk hagyatkozó alkalmazkodási folyamat elhúzódik. Ezzel (tehát az érvényben lévő Bretton Woods-i rendszerrel) szembeállította egy olyan rendszer képét, a mely rugalmas valutaárfolyamokon alapulna, így biztosítva az egyensúly fenntartását, mert ebben a rendszerben az árfolyamok alakulása automatikusan kiküszöbölné az egyes tagországok folyó fizetési mérlegeinek hiányát/többletét. Kevésbé ismert az, hogy Friedman a kisebb és nyitottabb - azaz 
az importárak versenyének erősebben kitett és az inflációjukkal megbirkózni nem tudó - országokat illetően elfogadta a „kemény”, nem kiigazítható módon rögzített valutaárfolyamot is: elismeréssel szólt a hongkongi, a helyi pénzt a dollárhoz kötő valutatábláról (Friedman [1989]). Emellett 1977-ben ilyen rendszer bevezetését javasolta Izraelnek, amely, úgy tünt, nem tud megbirkózni gyors inflációjával (Schiffman és szerzőtársai [2018]), korábban hasonló árfolyamrögzítést javasolt Jugoszláviának is a nyugatnémet márkához (Friedman [1973]).

Friedman gondolkodásában a „keményen” rögzített és a lebegtetett, egymásra látszólag semmiben sem hasonlító árfolyamrendszer abban „fért össze” egymással, ahogyan viszonyultak a kormányzat (diszkrecionális) monetáris politikájához. Az elöbbi kiküszöböli (lehetetlenné teszi) a kormányzat bármiféle monetáris politikáját, ha a tökemozgás liberalizált (ez a híres „lehetetlen hármasság”). ${ }^{2}$ Az utóbbi pedig - a fent mondottak értelmében automatikusan, tehát - a monetáris politikától függetlenül biztosítja a fizetési mérleg egyensúlyát. Így ebben az utóbbi rendszerben a monetáris politika - Friedman koncepciójának megfelelően - a pénztömeg egyenletes növelésére szorítkozhat. Más szóval, egyik esetben sincs szükség a valutaárfolyam alakulását (is) befolyásolni hivatott diszkrecionális döntéseket jelentő monetáris politikára. Az utóbbi fajta politikát Friedman egész pályafutása során a lehető legkártékonyabb kormányzati tevékenységnek, a (káros) inflációval való játszadozásnak tartotta, amely időről időre előidézi a valutaleértékeléseket és az ezek anticipálásán alapuló, kockázatmentes spekulációt. Ennek a politikának a kiigazítható módon rögzített valutaárfolyamok rendszere jelentette az alapját. A kiigazítható árfolyamok „köztes” rendszerével szemben Friedman dichotómiáját „sarokmegoldásoknak" szokták nevezni. ${ }^{3}$

1953-as írásában Friedman az alábbiak szerint írta le egy lehetséges monetáris unió körvonalait:

${ }^{2}$ A lehetetlen hármasság (impossible trinity) tétele értelmében, ha a nemzetközi tőkemozgás liberalizált (az ilyen liberalizálás az 1950-es években még nem terjedt el az Egyesült Államokon kívül, de a 20. század utolsó negyedétől egyre általánosabban elfogadottá vált), akkor rögzített valutaárfolyam mellett a kormányzatnak nincs módja monetáris (kamat-) politikát folytatni, illetve ha a kormányzat folytat monetáris politikát, akkor lebegtetnie kell valutája árfolyamát. Ezt a tételt Mundell-Fleming-tételnek is nevezik, mert ők ketten írták le egymástól függetlenül az 1960-as évek elején megjelent cikkekben (Fleming [1962], Mundell [1963], lásd még Boughton [2003]). A tétel természetesen meg is fordítható, és akkor úgy szól, hogy a lebegtetett árfolyam biztosítja az önálló monetáris politikát, „megvédi” folytatásának lehetőségét, elszigeteli a monetáris folyamatokat a külföldi befolyástól. A továbbiakban látni fogjuk, hogy a tételnek ez az utóbbi formája a nemzetközi pénzügyi integráció fejlődése folytán a világ nagy részén ma már nem áll (pontosabban csak egy jelentősen meggyöngített formában áll) fenn.

${ }^{3}$ A Friedman által kárhoztatott köztes megoldásnak lényegében megfelelő eset volt az európai árfolyam-mechanizmus (European Exchange Rate Mechanism, ERM) (jó ismertetést ad róla például Eichengreen [2019]). Ennek a GMU-val (az euróval) történő felváltását Friedman elhibázottnak tartotta. Az (akkori) EU-tagállamokat, illetve azok egységes valutát elfogadni készülő többségét gazdasági, politikai, kulturális szempontból túlságosan vegyes országcsoportnak tartotta, egy őket csupán lazán összefogó rendszer tagjainak, és esetleges aszimmetrikus sokkoktól féltette a visszavonhatatlannak szánt árfolyamrögzítést (Friedman [1997]). Azt már sohasem fogjuk megtudni, mit javasolt volna helyette. A kettő mellett harmadik lehetőség - ami csakis a szabad lebegtetés lehetett volna - fel sem merülhetett (lásd a későbbiekben Peter Kenen megállapítását). 
„Politikailag független és valutájukat, mondjuk, az aranystandardhoz keményen hozzákapcsoló csatlakozó országok egy csoportja ezzel a lépésével alávetné magát egy központi monetáris hatóságnak - igaz, ez a hatóság személytelen lenne. Ha ráadásul szilárdan elköteleznék magukat a javak, a személyek és a tőke szabad, korlátozásoktól mentes áramlása mellett, és a gazdasági feltételek az utóbbit könnyűvé tennék, akkor valójában egy gazdasági egység lennének, amelyben tökéletesen helyes lenne egységes - merev valutaárfolyamokkal egyenértékü - pénz alkalmazása." (Friedman [1953a] 193. o.)

Ehhez a szerző még hozzátette:

„...a rögzített árfolyamrendszer kereskedelmi korlátozások nélküli tartós működtetése megköveteli a belső monetáris és fiskális politikák összehangolását, továbbá szándékot és képességet arra, hogy legalábbis lényeges változtatásokat valósítsanak meg a külső feltételekben a belső ár- és bérstruktúra megfelelő módosításai révén." (Uo. 193-194. o.)

Friedmannek ez az írása nem tartalmazza az optimális valutaövezet kifejezést, de látni fogjuk, hogy a vonatkozó elmélet nem jelentéktelen része már benne volt ebben az írásban, és ez már tartalmazta az EU vezető szervei által 49 évvel később elfogadott európai Gazdasági és Monetáris Unió (GMU) számos fontos elemét is. Igaz, itt csak a monetáris politikák összehangolásáról volt szó, nem került szóba az európai központi bank. Ellenben az ár- és bérstruktúra átalakításának felvetésével nagyon fontos - csaknem két évtizeddel később Marcus Fleming által is tárgyalt, a GMU-ban máig is gondokat okozó - problémára mutatott rá (Fleming [1971]).

Az optimális valutaövezet elmélete megalapítójának általában Mundellt tekintik, és ezt Mundell [1961]-hez kötik. A cikk terjedelme legnagyobb részében a manapság „aszimmetrikus sokknak” nevezett problémával foglalkozik, illetve azzal, hogy ilyen sokk leginkább akkor érhet egy földrajzi régiót egy másikhoz képest, ha ezekben különböző gazdasági tevékenységeket végeznek, és így az egyik $(A)$ tevékenységét sújthatja termékeinek olyan keresletcsökkenése, amely a másikat $(B)$ nem érinti. Ha ez megtörténik, az árak és a bérek lassú alkalmazkodása - merevsége - miatt $A$-ban munkanélküliség és folyófizetésimérleg-hiány, $B$-ben infláció és folyófizetésimérleg-többlet lesz. Ha a két régióban közös a valuta, akkor ezen a bajon nem segít az, ha annak egyébként lebegtetett árfolyama van. Amennyiben azonban a két régióban külön-külön - egymáshoz nem kötött - valutát alkalmaznak, akkor $A$ valutájának leértékelődése elhárítja ezeket az egyensúlyzavarokat. Mundell ezek alapján hangsúlyozza, hogy az optimális valutaövezetet az idioszinkratikus kibocsátási szerkezetü régió, nem pedig az ország alkotja. De persze a valóságos világban a valuták az országok szuverenitásának kifejeződései, ezért az optimális valutaövezetnek közvetlen gyakorlati hasznossága csak ott lehet, ahol a politikai szervezödés változásban van - így a volt gyarmati területeken és Nyugat-Európában, ahol ezt vitatják is (Mundell [1961] 661. o.). Meg kell itt jegyezni, hogy az egyes régiók eltérő kibocsátási szerkezete és az optimális valutaövezetek közötti összefüggésről és a nemzeti valuták ennek ellentmondó rendszeréről korábban Abba Lerner is írt (Lerner [1944] 375-376. o.), gondolatait a téma kutatója, Cesarano [2006] szerint Mundell valószínüleg nem ismerte. 
Mundell érvelése kiegészült még azzal, hogy a különböző termelési szerkezetű régiók között még sincs szükség valutaárfolyam-rugalmasságra akkor, ha a termelési tényezők szabadon mozoghatnak köztük. A tényezők közül a szerző elsősorban a munkaerő mozgását hangsúlyozza (a fenti példában az $A$-ban munkanélküliekké válók átmennek $B$-be, ami feleslegessé teszi az árfolyammozgást).

\section{Robert McKinnon, Marcus Fleming és Peter Kenen}

McKinnon [1963] két fontos új elemet vitt be az optimális valutaövezetek elméletébe. Az egyik új elem a gazdaság nyitottságának foka. Lényegében arról van szó, hogy egy ország egy másik országgal (országcsoporttal) folytatott kölcsönös kereskedelmének súlya (pozitív előjellel) jelentős szerepet játszik annak meghatározásában, hogy elönyös-e számukra a közös valuta használata. A formális tárgyalás nem kereskedelemről, hanem kereskedhetö (tradable), azaz az export és az import tárgyát képezhető javakról szól, azok arányáról a termelésben vagy a belföldi felhasználásban. Ezek árát a valutaárfolyam változása sokkal inkább befolyásolja, mint a nem kereskedhető (nontradable), azaz a külkereskedelmi forgalomba nem kerülhető javakét. Tehát a saját valuta leértékel(öd)ése esetén az áraik emelkednek. McKinnon abból indul ki, hogy a leértékelés rendeltetése a folyó fizetési mérleg javítása. Ez a kereskedhető javak kibocsátásának növelését és belföldi felhasználásuk csökkentését követeli meg. Minél kisebb azonban a nem kereskedhető javak aránya, annál kevésbé lehet ezek elöállításából erőforrásokat átvinni a kereskedhetők elóállításába, ezért annál inkább előtérbe kerül a felhasználás csökkentése. Emellett a kereskedhető javak nagyobb súlya az általános árszínvonal alakításában is nagyobb szerepet ad ezen javaknak, ezért áraik emelkedése nehezebbé teszi az árszínvonal kontrollját. Tehát minél nyitottabb a gazdaság, annál előnyösebb a rögzített árfolyam. McKinnonnak ezt az érvelését Corden [1972] vitatta, de ez - részben más formában és érveléssel - ma is fontos eleme az optimális valutaövezetek elméletének.

Az optimális valutaövezetek elméletének másik McKinnontól származó új eleme az előbbire épül. Eszerint minél kisebb egy ország, rendszerint annál nyitottabb a gazdasága. Ezért a kisebb gazdaságok számára általában több előnnyel jár egy monetáris unióhoz való csatlakozás, mint a nagyobbak számára.

Fleming [1971] az inflációnak az árfolyamrögzítés szempontjából felettébb aggályos jelenségére irányította rá a figyelmet. Az egyszeri tényezőkből adódó (általa statikusnak nevezett) országközi inflációs eltérésektől megkülönböztette a dinamikus eltéréseket, amelyek a szakszervezeti tevékenység különböző erősségéből, az infláció és a munkanélküliség országok közt más-más mértékủ elfogadottságából adódnak. Márpedig a rögzített árfolyamokat alkalmazó országoknak egyforma ütemü inflációval kell rendelkezniük.

Kenen [1969] két fontos gondolattal gazdagította az optimális valutaövezetek elméletét. Az egyik a közös valuta használatára „jelölt” országok eltérő ágazati megoszlású kibocsátása és az aszimmetrikus sokkok veszélye közötti összefüggést érinti. Amilyen nyilvánvaló a priori az ilyen (Mundell által felismert) összefüggés 
létezése, ugyanolyan egyértelmű Kenen szerint az is, hogy ha az eltérő kibocsátási szerkezetek egyúttal erősen diverzifikáltak is, azzal kisebb az aszimmetrikus sokkokból származó bajok valószínűsége, mert a diverzifikáció nyilvánvaló védelmet jelent az egy-egy ágazatot érintő aszimmetrikus sokkok külkereskedelmi egyensúlyt rontó hatásával szemben azáltal, hogy ezek jó eséllyel kiegyenlítik egymást. A fejlett országok gazdasága diverzifikáltabb, ezért számukra célszerübb az (akkor még működő) Bretton Woods-i rendszerhez tartozás. A kevésbé diverzifikált fejletlenebb országoknak jobban megfelelhet valutaárfolyamaik időnkénti változtatása vagy akár azok lebegtetése. A diverzifikált kibocsátási szerkezet a munkaerő mobilitását is javíthatja, persze csak akkor, ha az érintett országok között szabadon mozoghat a munkaerő. Akkor a diverzifikált ágazati szerkezet általában kedvezőbb feltételeket teremt az ilyen mozgáshoz, ami ugyancsak kedvez az árfolyam rögzítésének. Meg kell itt jegyezni, hogy a diverzifikált kibocsátási szerkezetnek ehhez képest fordított hatású szerepet tulajdonított McKinnon [1969], amely szerint az ilyen szerkezet a külkereskedelem kisebb szerepét vonja maga után, amivel csökken a rögzített árfolyam előnye. Persze az ágazaton belüli kereskedelem elmúlt évtizedekben tapasztalt, korábban elképzelhetetlen mértékü növekedésének körülményei között ez az ellenvetés nem állja meg a helyét.

A másik Kenen [1969] által felvetett fontos - és máig is sok fejtörést okozó - hozzájárulás a monetáris és a költségvetési integráció „ikrekként” kezelése: az a nézet, amely szerint a monetáris integráció megköveteli az érintett országok közötti költségvetési integrációt is. Mégpedig azért, hogy az esetleges aszimmetrikus sokkok okozta problémákat - amelyek kezelésére a közös monetáris politika nem lehet alkalmas adópénzek tagállamok közötti átcsoportosításával kezelni lehessen. ${ }^{4}$

\section{A monetáris unió a megvalósulás útján, I. - endogenitások az optimalitási feltételek teljesülésének alakulásában}

Az egyszer létrejött monetáris unió fontos tulajdonsága, hogy müködése folyamán változik (az ezt tárgyaló irodalom nagyobb része szerint növekszik) optimalitásának foka. Ez azt jelenti, hogy ha az optimalitási feltételek nem vagy csak kevéssé teljesültek az unió létrejöttekor, később teljesülni fognak (nagyobb mértékben fognak teljesülni). Az ilyen fejlődést az irodalom az optimalitási feltételek endogenitása elnevezés alatt tárgyalja (például Mongelli [2008]).

\footnotetext{
${ }^{4}$ Kenennek ez a gondolata nem volt előzmény nélküli. Az Egyesült Államokban az 1930-as években némely bankok hatalmas veszteségei a nekik nyújtott segítség révén jelentős mértékben csökkentették a központi bank (Federal Reserve System, Fed) aranykészletét. A bankok akkor általában regionális érdeküek voltak, és egyes tagállamok vezetőinek nem tetszett az, hogy mások hibáiból csökkent a közös aranykészlet. Emiatt felmerült a monetáris dezintegráció lehetősége, amit a szövetségi költségvetés támogatása hárított el. Penelope Hartland erről szóló írása ugyan nem említette kifejezetten a monetáris és a fiskális integráció közötti „ikertestvéri” kapcsolatot (Hartland [1949]), Forrest Capie mégis teljes joggal állapította meg, hogy itt annak a gondolatnak az előzményéről van szó (Capie [1998]).
} 


\section{A kereskedelem növekedése és az aszimmetrikus sokkok}

Az endogenitás legtöbbször tárgyalt eleme az, hogy a monetáris unió a tagjai közötti kereskedelem növekedésének irányába hat (lásd például Benczes [2014]). Az árfolyamkockázat megszủnése, a transzparencia javulása és a verseny erősödése állhat amögött, hogy a közös valuta növeli a kereskedelmet. Ezt az állítást empirikusan igazolta többek között Frankel-Rose [1998], Rose [2008], McCallum [1995] és Helliwell [1998]. Tehát az optimális valutaövezetek elmélet szerint növekednek a monetáris unió előnyei.

Itt azonban a fordított irányú hatás lehetősége is felmerül. Az ugyanis vitatott, hogy a kereskedelem növekedése csökkentheti vagy növelheti az aszimmetrikus sokkok előfordulását. Paul Krugman szerint ez a növekedés területek/országok közötti specializációhoz vezet, ahogyan ez az Egyesült Államok tagállamai között történt, és ezzel növekszik az aszimmetrikus sokkok veszélye, ami a monetáris unió szempontjából hátrányt okoz (Krugman [1991/2003]). Empirikus kutatások azonban arra mutatnak, hogy - legalábbis egyelöre - az EU (és azon belül az euróövezet) tagállamai között a kereskedelem növekedésével a specializálódás helyett inkább az ágazaton belüli kereskedelem erösödik, ami az aszimmetrikus sokkok csökkenése, a kibocsátásingadozások párhuzamossága irányába hat (Fidrmuc [2001], Kenen [2003] 34. o., Molendowski [2014], Dautovic és szerzötársai [2014]).

A monetáris unió előmozdítja a tagjai közötti pénzügyi integrációt. Ez nem meglepö, hiszen az árfolyam-ingadozások veszélyének megszünése kevésbé kockázatossá teszi külföldi eszközök megszerzését. Így a (jövendőbeli) tagállamok között a hitelés tőkepiacok (addig természetesen csigalassúságú) integrálódása már az euróövezet 1999. évi megalakulásának előszelére felgyorsult, majd tovább gyorsult. A 2008-as válság és még inkább az azt követő euróválság (amelynek folyamán voltak kételyek az euróövezet fennmaradását illetően is) visszavetette ezt a fejlödést, de azért nem a 2000 elötti szintre. Majd lassan ismét erősödött a hitel- és tőkepiacok integrációja. A Covid-19-válság is visszavetette a fejlődést - de az előző válságnál kisebb mértékben -, és az EU közös helyreállítási alapjáról 2020 júliusában született megállapodással újra erösödött az integráció, amelynek alakulását az Európai Központi Bank statisztikái és tanulmányai nagy figyelemmel követik. ${ }^{5}$

Rá kell itt mutatnunk a fordított irányú összefüggésre is: a pénzügyi integráció erősödése igen nagy jelentőségü a monetáris unió zökkenőmentes müködése szempontjából. Atkeson-Bayoumi [1993] és Asdrubali és szerzőtársai [1996] írtak először arról a fontos szerepről, amelyet a pénzügyi integráció játszhat, és játszik is az Egyesült Államokban, ahol ez - tehát a hitel- és tőkepiacok tagállamok közötti összefonódása - nagyon erős. Az ilyen összefonódás ugyanis tompítja a monetáris unió körülményei között egyébként súlyos problémákat okozni képes aszimmetrikus sokkok következményeit. Ezt a megfigyelést más empirikus vizsgálatok is alátámasztják.

\footnotetext{
${ }^{5}$ A pénzügyi integrációt jellemző adatok az EKB honlapján a https://www.ecb.europa.eu/stats/financial_ markets_and_interest_rates/financial_integration/html/index.en.html cím alatt találhatók. A témáról szóló tanulmányok egy régebbi példája ECB [2007], egy újabb ECB [2020a] (lásd még ECB [2020b]).
} 
Hoffmann-Sørensen [2012] becslése szerint az Egyesült Államokban a tőkejövedelmek tagállamközi mozgása kiegyenlíti a tagállamok között a különféle aszimmetrikus sokkok által okozott jövedelemkülönbségek 40 százalékát, 25 százalékot egyenlítenek ki a hitelpiacok, a szövetségi kormányzat költségvetési transzfereinek hozzájárulása csupán 10-15 százalék, és 20-25 százalék kiegyenlítetlen marad. Természetesen az európai GMU-nak (a tagállami hitel- és tőkepiacok összefonódásának) még sokat kell fejlődnie ahhoz, hogy hasonló eredményeket hozzon.

A pénzügyi integráció ilyen szerepének felismerése nyomán a korábbinál kisebb jelentőséget kell tulajdonítanunk annak a (mint láttuk, Kenentől származó) követelménynek, hogy a monetáris uniót kísérje költségvetési unió is.

A pénzügyi integráció egyik fontos velejáróját alkotják az országhatárokat átszelö bankintegrációk. Az amerikai tapasztalatok szerint az ilyen integrációk maguk is erősítik a gazdasági teljesítmények ingadozásainak párhuzamosságát, tehát az aszimmetrikus sokkok ellen hatnak. ${ }^{6}$

A tagországok közötti pénzügyi integráció fejlődése csökkenti - és az euróövezetben is tovább fogja csökkenteni -, de nem szünteti meg a közös költségvetési tevékenység szükségességét. Mint láttuk, az Egyesült Âllamokban a tőke- és hitelpiacok elsődleges szerepet játszanak az egyes tagállamokat érintő aszimmetrikus sokkok jövedelmi következményeinek kezelésében. Azt azonban nem feledhetjük el, hogy ez túlnyomórészt a tőkejövedelmeket érinti. Ami az ottani szövetségi költségvetési integrációt illeti, annak nincsenek kifejezetten a tagállamokat érő aszimmetrikus sokkok kezelésére irányuló elemei. A szövetségi jövedelemadó progresszivitásának azonban van jövedelemingadozásokat simító hatása (Atkeson-Bayoumi [1993], Asdrubali és szerzőtársai [1996]). Emellett az is nagyon fontos, hogy az Egyesült Âllamokban az „állami” nyugdíj szövetségi szintű, nagyobb részben szövetségi finanszírozású rendszer, és ez érvényes az egészségbiztosításra (Medicare), valamint az alacsony jövedelmüek egészségügyi célú támogatására (Medicaid) is. A munkanélküliség jelentős mértékű növekedése esetén szövetségi eszközökkel egészítik ki a munkanélküliek állami szintű támogatását is. Mindez jelentős részben függetleníti a szociális kiadások szféráját az egyes tagállamokat érő aszimmetrikus sokkok költségvetési hatásától (Kirkegaard-Posen [2018]). Ez pedig nem más, mint egy bizonyos fokú költségvetési integráció.

\section{Kis lépések a költségvetési integráció felé}

A Kenen által felvetett, a monetáris integráció müködéséhez szükséges költségvetési integrációról szóló gondolat általában (Kenennél nem, másoknál annál gyakrabban) abban a formában merül fel, hogy követni kellene az Egyesült Államok előbb vázolt mintáját.

\footnotetext{
${ }^{6}$ Az Egyesült Államokban az összefüggés vizsgálatához szinte „laboratóriumi” körülményeket teremtett az 1994. évi, úgynevezett Riegle-Neal-törvény, amely megszüntette az államközi bankolás és bankintegrációk (egyesülések és felvásárlások) 1927-től bevezetett tilalmát (Goetz-Gozzi [2020]).
} 
Rövid és középtávon azonban az EU (az euróövezet) költségvetési rendszereit aligha lehet különösebben közelíteni a leírt amerikai költségvetési intézményekhez. Az EU közös költségvetése - amely egy-egy évben a közösségi GDP egy százalék körüli hányadát osztja el - egyelöre igencsak sovány költségvetési integrációt testesít meg, amely szinte teljesen alkalmatlan a tagállamokat érö aszimmetrikus sokkok következményeinek simítására. Van-e mégis az európai monetáris integrációban endogén tendencia a tagállamok közötti költségvetési integráció erősítésére?

Elöször a 2010-ben kezdődött euróválság során és azóta több különböző program keretében az EKB jelentős összegekben vásárolt a válságországok államkötvényeiböl, 2012 öszén pedig - az új EKB-elnök, Mario Draghi híres júliusi beszéde (Draghi [2012]) alapján - meghirdette az azonnali készpénzes vásárlások (Outright Monetary Transactions, OMT) programját. Az EKB (német) fö közgazdásza, Jürgen Stark már 2011-ben lemondott, mert úgy vélte, hogy az EKB kötvényvásárlásai legalábbis potenciálisan sértették a maastrichti szerzödés azon szabályát, amely tiltja, hogy egy euróövezeti tagállam adóssága egy másik tartozásává váljék (Müller és szerzőtársai [2011]). Később az azonnali készpénzes vásárlásokat hasonló alapon szélesebb körü, éles bírálatok érték (lásd például Sinn [2018] 7. o.). Nem egyértelmü, hogy az EKB az ilyen - a tagállamok nemzetközi fizetőképességének megítélését általában javító (Fabiani és szerzőtársai [2021]) - akcióival túllépett a monetáris politika szokásos keretein (mert állampapírokat minden központi bank szokott vásárolni). Így az sem bizonyos, hogy a költségvetési integráció felé tett lépésekről volt itt szó. Az azonban már aligha vitatható, hogy az euróövezet válságországainak nagyon olcsó hitelekkel való támogatására szolgáló, 2010-ben létrehozott ideiglenes Európai Pénzügyi Stabilitási Eszköz (European Financial Stability Facility, EFSF) és az azt 2012-ben felváltó, immár tartós müködésre szánt Európai Stabilitási Mechanizmus (European Stability Mechanism, ESM) és ugyanígy a 2020-2021-ben kidolgozott és jóváhagyott, a Covid-19-válsághoz kapcsolódó helyreállítási terv (ET [2021]) a költségvetési eszközök országok közötti újraelosztásáról szól, és így költségvetési integrációs intézkedésnek tekinthető.

Ezek a fejlemények arra mutatnak, hogy a monetáris integrációban érvényesül endogén tendencia a költségvetési integráció felé való haladásra. Amikor a monetáris unió fenntarthatósága egyes tagállamok súlyos nehézségei folytán veszélybe került, akkor megszülettek a veszély elhárítására alkalmas (a fenntarthatóság biztosítására irányuló, lásd Losoncz [2019], Soós [2019]) költségvetési intézmények. Ennek a mechanizmusnak a megszủnése, az euróövezet súlyos következményekkel fenyegető szétesésének vállalása alaposan megváltozott politikai döntési mechanizmusokat feltételez. Nehéz elképzelni az ilyen változások gyors megvalósulását. Arról pedig, hogy mi történhet évtizedek múlva, aligha érdemes spekulálni.

\section{Az inflációs különbségek nem fájdalommentes csökkentése}

A közös pénzt használó országok inflációs ütemei közötti különbségek aszimmetrikus sokkokhoz vezetnek (más értelmezés szerint jelenthetik ilyen sokkok következményeit). Az érintett országokban az euró bevezetését megelőző és közvetlenül követő évek 
folyamán tendencia mutatkozott a bérek és fizetések bizonyos fokú stabilizálódására: a növekedés többnyire lelassult ott, ahol korábban gyors volt. Ezt Calmfors [2001] és Pichelmann [2003] összekapcsolták azzal, hogy akkoriban több érintett ország kormánya ismét alkalmazni kezdte a „divatból” korábban kiment jövedelempolitikát, és így felmerült az a gondolat, hogy a bér- (és persze ezzel együtt az ár-) rugalmasság javulása ugyancsak endogén hatása a monetáris uniónak (De Grauwe [2003]).

Sajnos azonban ez az endogén hatás később, a 2007-2008-ban kezdődött nemzetközi pénzügyi és gazdasági válságig és tovább, az abból 2010-ben „kinőtt” euróválságig nem látszott müködni. Kenen [2003] már nagyon korán megállapította azt, hogy a monetáris unióban - a nagy remények ellenére - fennmaradtak a tagországok közötti inflációs különbségek. Az „inflációs fegyelem” csatlakozás utáni csökkenése a később csatlakozók körében is okozott problémákat (Bod és szerzőtársai [2020]). Az 1. ábrában bemutatjuk a munka névleges egységköltségének (Nominal Unit Labour Cost, NULC) 2000-2020 közötti alakulását Németországban és öt olyan euróövezeti tagországban, amelyeket általában a kérdéses válságot súlyosan megszenvedőknek, válságországoknak tartanak.

1. ábra

A munka névleges egységköltsége, 2000-2020 (négy negyedéves mozgóátlagok, 2010 átlaga $=100)$

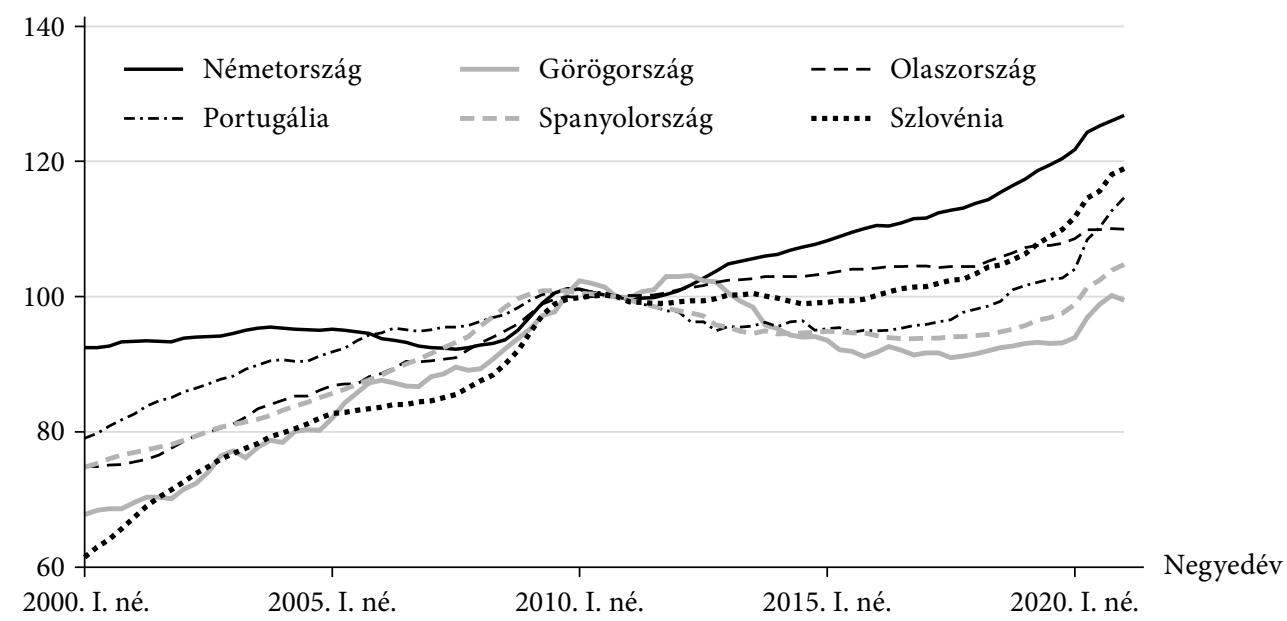

Megjegyzés: Szlovénia adatai 2006-ig tolárban vannak megadva.

Forrás: Eurostat.

A többi ország 2010 előtt a némethez képest gyorsabb inflációjának több fontos oka is volt: az 1. hatás a kormányzati gazdaságpolitikák különbségei, a 2. hatás az úgynevezett Balassa-Samuelson-hatás, amely alapján a gyorsabb gazdasági növekedés a lassabbhoz képest többletinflációt generál (lásd Begg és szerzötársai [2003], MihaljekKlau [2003]), a 3. hatás az a különbség, amely Hall-Soskice [2001] leírása szerint abban áll, hogy az északi EU-tagállamok „,koordinált piacgazdaságaiban” a bérek és keresetek növekedése sokkal inkább kontrollálható, a termelékenység növekedésével jobban 
összehangolható, mint a déli tagállamokban, ahol ezt egymással versengő szakszervezetek tevékenysége nehezíti.

Hall-Soskice [2001] „koordinált piacgazdaságokként” írja le az északi államok csoportját, amelyeket exportvezérelt növekedéssel, a bérek koordinált és mértéktartó növekedésének támogatására alkalmas szakszervezetek jelenlétével jellemez. Ezzel szemben a déli országokban (a válságországok - Írország kivételével - ebbe a csoportba tartoznak) egymással versengő szakszervezetek teszik nehézzé a béremelkedés koordinálását, és ez inflációs hatással jár.

Az euróövezet országainak béralku- és bérkoordinációs rendszereit elemzi HöpnerLutter [2014]. A szerzőpáros azt vizsgálja, hogy e rendszerek tíz fö dimenziójának változatai (egyéb tényezők, például a GDP-növekedés üteme mellett) hogyan befolyásolják az önmérsékletre való hajlandóságot a bérek emelésében. A tíz dimenzió között szerepel például a dolgozók szakszervezeti szervezettségi hányada, a béralkuba való kormányzati beavatkozás mértéke stb. A szerzőpáros azt találta, hogy az euróövezetben a munkaegységköltség átlag alatti növekedése csak olyan országokban volt megfigyelhetö, amelyekben „a szociális partnerségnek mély gyökerei voltak, amelyekben a bérkoordináció erősen intézményesített volt, és amelyeket évtizedek óta »korporatív irányzatúaknak« tartottak" (i. m. 19. o.). Ezek a sajátosságok sokkal inkább jellemzők voltak az északi, mint a déli országokra.

Végül, érvényesült egy olyan, 4. hatás is, amelyet gyakran - de tévesen - magának a monetáris integrációnak tulajdonítanak: eszerint ugyanis a közös pénz nemcsak nem mérsékli, hanem egyenesen növelné a tagországok közötti inflációs különbségeket. Nevezetesen, az 1-3. ok alapján adódó inflációs különbségek és a monetáris unióban az egységesség felé erősen tendáló kamatláb körülményei között a gyorsabb inflációjú országokban (tehát ott, ahol az infláció üteméhez képest alacsonyabbak voltak a kamatlábak) nyilvánvalóan erősebben voltak ösztönözve a beruházások - köztük a spekulációs célú beruházások -, ami ezekben az országokban tovább növelte az inflációt (lásd például Diaz Sanchez-Varoudakis [2013]).

Ezt a 4. hatást azért tévedés a monetáris uniónak tulajdonítani, mert az infláció üteméhez képest alacsony kamatoknak a 2008-as válság előtti fél évtizedben történt elszaporodása távolról sem korlátozódott az euróövezet érintett tagállamaira. A jelenség nem tulajdonítható a monetáris integrációnak. Itt valójában az (alább tárgyalandó) pénzügyi integrációnak, a bank- és más pénzügyi közvetítő rendszerek, hitelés tőkepiacok kiterjedt nemzetközi összefonódásának a következményéről van szó. Fogalmazhatunk úgy is, hogy a kérdéses folyamat kibontakozásához nem volt szükség a monetáris integrációra; elegendő volt a pénzügyi integráció - mégpedig annak nem igazán magas szintje - is. (Gondoljunk csak arra, hogy a monetáris integráción kívül maradt Magyarországon hogyan és milyen következményekkel valósult meg az inflációs folyamataihoz - és a forintkamatlábakhoz - képest olcsó devizahitelek robbanásszerü növekedése.)

\footnotetext{
${ }^{7}$ Martin Sandbu kitűnő elemzésének összefoglalása szerint a 2000-es évek első felében „a hitelfelvétel költségeinek csökkenése lehetett a gazdasági ciklusok divergálásának oka, de az eurót emiatt aligha lehet hibáztatni, mert ez a jelenség mindenütt megfigyelhető volt” (Sandbu [2015] 47. o.).
} 
Az inflációs többlet az érintett országoknak két súlyos bajt okozott. Az egyik az export- és import-versenyképesség romlása ${ }^{8}$ (Krekó-Oblath [2020] alapos empirikus elemzéssel mutatja ki ezt), hiszen az árfolyam rögzítése kizárja az inflációs többletből adódó reálfelértékelődés valutaleértékeléssel való megszüntetését. A másik baj a konjunktúra túlpörgése, a gazdaság túlfütése. Folyó fizetési mérlegeik hiánya fenntarthatatlan mértékben megnövekedett (Diaz Sanchez-Varoudakis [2016]).

Csakhogy az 1. ábra azt is megmutatja, hogy 2010 után a tendencia megfordult. $\mathrm{Az}$ addig leglassabb munkaegységköltség-növekedést mutató Németország most az élre került. A válságországokban erősen lelassult a munkaegységköltség-növekedés, Görögországban, Portugáliában és Spanyolországban (rövid) csökkenési periódusok is voltak. Így aztán végső soron mégsem megalapozatlanok azok a fentebb említett nézetek, amelyek szerint a bér- (és persze ezzel együtt az árrugalmasság javulása a monetáris unió endogén hatása. Ez a hatás azonban a korábban reméltnél sokkal kevésbé gyorsan, vele ellentétes folyamatok durva, válságjellegü letöréseként érvényesült; deflációs veszéllyel, részben tényleges deflációval, tehát nagyon káros gazdasági jelenségekkel járt együtt. Ugyanakkor nem változtak a béremelkedések mechanizmusai. Nem változott az, hogy Németországban (és a többi északi tagállamban) a termelékenység növekedésével jobban összehangolható a bérek és keresetek növekedése, mint a déli tagállamokban, ahol ezt egymással versengő szakszervezetek tevékenysége nehezíti. Nem tudjuk, hogy a jövőben ebböl nem fakadnak-e majd a korábbiakhoz hasonló feszültségek, és ha igen, könnyebb lesz-e azok feloldása.

\section{A monetáris unió a megvalósulás útján, II. - egy új optimális valutaövezeti elmélet születése}

Az optimális valutaövezetek elméletének (itt már hozzá kell tennem: az optimális valutaövezetek hagyományos elméletének, amelyet hagyományos elméletnek nevezek) tárgyalását itt befejeztem, és ebből kitünik, hogy az elmélet az 1970-es évek eleje óta lényegében nem gazdagodott új elemekkel. Kivételt csak az endogenitás feltevései, elemzései jelentenek. Ezek is csak közel két évtizedes szinte teljes szünet után jelentek meg, ami miatt viszonylag kevés érdeklődés mutatkozott a téma iránt. Az újabb élénkülés az 1980-as évek végén kezdődött, amikor az európai közös valutát megteremtő maastrichti szerződés lassú, 1992-ben véget ért megszületésével konkrét tervvé vált az európai monetáris integráció évtizedek óta emlegetett, de addig formát ölteni nem látszó elgondolása.

Az újabb élénküléssel Bayoumi-Eichengreen [1997] szerint az optimális valutaövezetek elmélete „csak minimális mértékben” haladt előre Mundell, McKinnon és Kenen fent tárgyalt munkáihoz képest. Amennyiben az eddig tárgyalt - a hagyományos - elméletről van szó, annyiban ez persze igaz, de ugyanakkor jelentős változások

\footnotetext{
${ }^{8}$ Az inflációs tényezők közül a 2. hatásnak - a Balassa-Samuelson-hatásnak - nincs ilyen szerepe, mert az csak a nem kereskedhető (non tradeable) javak és szolgáltatások árait érinti (emeli) (Mihaljek-Klau [2003]).
} 
történtek, olyannyira, hogy az eddigi optimális valutaövezetekre vonatkozó elmélet mellett egy másik elmélet születéséről lehet beszélni.

Az új elmélet születését az alapozta meg, hogy az 1970-es évek eleje után eltelt két évtizedben sokat változott a nemzetközi pénzügyek világa. A Bretton Woods-i rendszer 1971-ben kezdődött, fokozatos megszünése után három, számunkra fontos területen változott, részben Európában, lényegében csak a monetáris integrációra való készüléssel összefüggésben, részben attól függetlenül és Európán kívül is.

1. Nagyon sok - és nagyon nagy részben kedvezötlen - tapasztalat gyült össze a rugalmas (lebegtetett) valutaárfolyamok müködésével kapcsolatban.

2. Egyre több ország liberalizálta a töke kivitelét és behozatalát (a Bretton Woods-i időkben ilyen liberalizált rendszer lényegében csak az Egyesült Államokban volt). Az is ösztönözte a liberalizálást, hogy a kereskedelmi kapcsolatok növekedése és még inkább az országok közötti kereskedelem növekvő részének nemzetközi vállalatok belső forgalmává alakulása - a hitel- és tőkepiacok integrálódási tendenciáival együtt - amúgy is nehézzé tette a korlátozások érvényesítését.

3. Az Európai Közösségekben (1992-től az Európai Unióban) a rugalmas árfolyamrendszert sohasem tudták elfogadni. Már 1972-től - amikor a Bretton Woods-i árfolyamrendszer még nem is szűnt meg teljesen - egymáshoz kötötték (változtathatóan rögzítették) valutáik árfolyamát, 1978-ban pedig ezt a rendszert jobban megszervezett formába hozták (Európai Monetáris Rendszer, EMS), és ebből már nehéz lett volna elképzelni valamifajta visszatérést a rugalmas árfolyamokhoz (Eichengreen [2019]).

Ad 1. Fent idéztük Friedman írását [1953b], amelyben a Bretton Woods-i rögzített árfolyamok rendszerét bírálva arról írt, hogy egy rugalmas árfolyamrendszerben az árfolyamok változása automatikusan kiküszöbölné az egyes tagországok folyó fizetési mérlegeinek hiányát/többletét. Az ezredforduló körüli évekig összegyűlt tapasztalatok fényében már nagyon sokan egyáltalán nem így gondolkoztak ezekről a dolgokról. Willem Buiter, aki korábban a Bank of England monetáris tanácsának tagja volt, az Egyesült Királyság euróövezethez való csatlakozását javasolva azt írta, tévedés azt gondolni, hogy

„a független nemzeti monetáris politika és az ehhez tartozó rugalmas nominális valutaárfolyam hatásosan használható aszimmetrikus sokkok ellensúlyozására, sőt azok semlegesítésére. Ez a »finomszabályozás-illúzió« összekapcsolódik azzal, hogy nem értik meg, hogy a nemzetközi pénzügyi integráció magas szintjének körülményei között a piac által meghatározott valutaárfolyamok a sokkoknak és az instabilitásnak elsősorban a forrását alkotják." (Buiter [2000] 1. o., kiemelés az eredetiben - S. K. A.)

A szerző hozzáteszi: nem ismer olyan bizonyítékot, amely alátámasztaná azt, hogy a rugalmas árfolyam a sokkok ellensúlyozására alkalmas lenne.

Ad 2. A tőke megnövekedett nemzetközi mobilitása alapvetően megváltoztatta az árfolyamrendszerek működési feltételeit. A probléma megvilágításában (a probléma és persze nem a később történt változás megvilágításában) nem másra, mint Mundellra tudunk hivatkozni, éspedig 1961. évi iskolateremtő cikkének néhány soha 
senki által nem idézett, teljesen elfelejtettnek tünő mondatára. A cikk következtetéseiben (Mundell [1961] 664. o.) találhatók utalások arra, hogy a szerző egy korábbi írása szerint a lebegő árfolyam „kifejezetten káros” is lehet akkor, ha a tényezők szabadon mozoghatnak a nemzeti határokon keresztül - és itt, a cikk korábbi részeitől eltérően, nem a munkaerő, hanem a tőke mozgásáról van szó. A szerint az írás szerint ugyanis

„[a] rugalmas árfolyamrendszer rosszul müködik, ha a tőke mobil, mert a kamatláb közvetlenebb hatással van a fizetési mérlegre [a tőkemozgásokra - S. K. A.], mint arra a piacra (az áruk és szolgáltatások piacára), amelyre reagál; viszont hatásosan működik, ha a töke immobil, mert [akkor - S. K. A.] ez a visszahatás kicsi vagy semmilyen." (Mundell [1960] 250. o.)

Nem szerencsés (és nem is logikus) az, hogy Mundell [1961] néhány, ide vonatkozó mondata a következtetésekbe, ott is részben - ráadásul nehézkes fogalmazásban - lábjegyzetbe került. Ennek szerepe lehetett abban is, hogy az egyébként rendkívül értékes írást nem volt könnyű publikálni. A cikket a szerző először az Economic Journalnak adta le, amelynek akkori szerkesztője, Roy Harrod megtagadta a közzétételét (lásd Mundell [1997]). Azonban egy írás tartalmának megtalálása mégiscsak az olvasó felelössége. El lehet gondolkozni azon, hogyan olvasunk egy hétköznapi írást akkor, ha egy Nobel-díjjal jutalmazottat így olvasunk. Márpedig így olvasta azt mindenki. Nincs szó a tỏke mozgásának korlátairól (vagy a mozgás szabadságáról) - lásd például Dellas-Tavlas [2009] (19. o.) fölsorolásában az azokról a feltételekről mondottakat, amelyek között a Mundell [1961]-ben megalkotott optimálisvalutaövezet-elmélet szerint a rögzített árfolyam jó. Ehhez (csak) a munkaerő mobilitására és/vagy bér- és árrugalmasságra van a szerzők tudomása szerint szükség, valamint arra, hogy a résztvevőket (országokat) ne sújtsák aszimmetrikus sokkok. Paul de De Grauwe is ezt adta elö (De Grauwe [2006] 2-3. o.), Buiter [2000] szerint pedig ezt az optimálisvalutaövezet-elméletet, „úgy tűnik, olyan világban dolgozták ki, amelyben nincs nemzetközi tőkemozgás" (1. o.).

Ugyancsak a nemzetközi tőkemozgások ügyéről nem tudó optimális valutaövezeti elméletről írt számos - köztük nem egy Nobel-díjas - amerikai közgazdász, és hadd említsek még egy európait: Václav Klaust, aki neves közgazdászként és politikusként is ismert (Klaus [2004]).

Maga Mundell egyáltalán nem kifogásolta cikkének ezt a sajátos „csonkítását” - nem találunk ilyesmit a Nobel-díj elfogadásakor tartott beszédében (Mundell [1999]) sem. Egy 1996. évi előadásában (Mundell [1997]) tett érdemi, tartalmi utalásokat az 1961-es cikkére - de természetesen akkor annak nemcsak az aszimmetrikus sokkokkal összefüggő, hanem az országok közötti tőkemozgásokkal összefüggő gondolataira is. Itt egyebek mellett azt is hangsúlyozta (uo. 35. o.), hogy csak olyan országoknak célszerủ csatlakozniuk valutaunióhoz, amelyek nem akarják gazdaságukat egymástól eltérő inflációs rátákkal működtetni (a másokétól eltérő inflációs ráta mint aszimmetrikus sokk - vagy ilyen sokkok következménye - nem szerepelt az 1961-es cikkében).

Említett 1996. évi előadásán kívül Mundell tudomásom szerint sohasem tért vissza az aszimmetrikus sokkok témájára, annál többet foglalkozott a tőke nemzetközi mobilitása és az árfolyamprobléma közötti összefüggéssel. Ez elöször két 1973-as írásában került elö, és ezekben egy másik, kapcsolódó gondolatot is fölvetett (Mundell [1973a], [1973b]). Nevezetesen, rámutatott arra, hogy a közös valuta egyfajta biztosítást is jelent a valutaközösség tagállamai számára. Például nemzetközi fizetési zavaraik esetén fontos 
az, hogy valutájuk mögött (egy közös központi bankban, vagy ha ilyen nincs, a többiek központi bankjaiban) az egy-egy tagállamhoz tartozónál több valutatartalék van. Ez ugyanis megakadályozza a valuta túlzott leértékelődését, tulajdonképpen az egész tartalék külön-külön mindegyik tagállam fizetéseihez rendelkezésre áll biztosítékként. Itt lényegében annak a jelenségnek egy eleméről van szó, amelyet pénzügyi integrációnak nevezünk. (Az utóbbi és a monetáris integráció közötti pozitív kapcsolatról ugyanabban az évben James Ingram is írt, lásd Ingram [1973].)

Mundellnek ezeket a későbbi írásait - az 1961. évivel mint Mundell I-gyel összehasonlítva - De Grauwe [2003] és [2006], valamint McKinnon [2004] Mundell II-nek nevezte. Ez a szembeállítás nem igazán indokolt. Alapja ugyanis lényegében az lenne, hogy Mundell [1973a]-ban a tőkemozgás szabadsága és a jó árfolyamrendszer közötti összefüggés újdonság Mundell [1961]-hez képest, ami tévedés. Annyi persze állítható lett volna, hogy az összefüggés tárgyalása Mundell [1961]-ben kevéssé volt hangsúlyos, és ez magyarázható azzal - amit egyébként De Grauwe [2006] és Szijártó [2017] említ -, hogy a cikk írása idején a tőkemozgás szabadságát az Egyesült Államokon kívül gyakorlatilag sehol sem biztosították.

A tőke nemzetközi mozgásának kiterjedt liberalizálása és az ezen alapuló, erősödő nemzetközi pénzügyi integráció az itt leírt értelemben kártékony hatásúvá tette a valutaárfolyamok lebegtetését. Továbbá nagyon jelentősen gyöngítette a lebegtetett valutaárfolyam azon tulajdonságát, hogy „megvédi” az önálló pénzügypolitika folytatásának lehetőségét (ez a „védelem” a már említett lehetetlen hármasság következménye, ha úgy tetszik, annak egyik kifejezési formája). ${ }^{9}$ A nemzetközi pénzügyi integráció különféle fejlödési formái - a bankok és más vállalkozások (és rajtuk kívül kötvényvásárlás formájában a háztartások) határokon átívelő hitelnyújtásai és -felvételei, a külföldi tulajdonlás fajtáinak és méreteinek nagymérvü bővülése - azzal a következménnyel járnak, hogy a kamatok mozgása olyan országok között is párhuzamosságokat mutat, amelyek valutaárfolyamait lebegtetik. Ez gyakorlatilag elsősorban a fontos nemzetközi szerepet játszó dollár és az azt kibocsátó amerikai központi bankrendszer (Fed) határokon átívelő szerepét, az amerikai monetáris politika által más országok pénzügyi folyamataira gyakorolt erős ráhatást jelenti (lásd például Ahmed és szerzőtársai [2021]). [De korábban a (nyugatnémet) márka is és újabban pedig az euró is részben ezt a szerepet játszotta/játssza az európai kontinens Európai Közösségen/Unión kívüli országaiban.]

A nemzetközi pénzügyi integráció terebélyesedésének ezzel a fontos és viszonylag új következményével az irodalomban föleg Hélène Rey, Pierre-Olivier Gourinchas, Maxime Sauzet, Peter Montiel és Peter Pedroni (Rey [2016], Gourinchas és szerzőtársai [2019], Montiel-Pedroni [2019]) foglalkoztak. Hélène Rey rámutatott arra, hogy különféle empirikus kutatások eredményei szerint azért az új körülmények között is

\footnotetext{
${ }^{9}$ A lehetetlen hármasságról lásd a 2. lábjegyzetet. A tétel szerint ha két ország valutája azonos, vagy (csak) azok árfolyama rögzített, és köztük szabad a tőkemozgás, akkor legalábbis nagyon erősen korlátozott a lehetőség arra, hogy különböző monetáris politikákat folytassanak. És megfordítva: lebegő árfolyamok esetén a monetáris politikák nincsenek így összekapcsolva, mert a kamatok egyik országban történt változ(tat)ására a piac és/vagy a másik ország kormányzata nem (nem szükségképpen) kamatváltoz(tat)ással, hanem rendszerint inkább a valutaárfolyam olyan változtatásával - vagy változni hagyásával - reagál, amely kielégíti a fedezetlen kamatparitás követelményét. Ebben áll az önálló monetáris politika „megvédése”.
} 
megmarad valami a lebegtetett árfolyamok monetáris autonómiát védő szerepéből. Nevezetesen az ilyen árfolyamot alkalmazó országok rövid lejáratú pénzpiaci kamatlábainak alakulása gyöngébben korrelál a „bázisország” (többnyire az Egyesült Államok) megfelelő kamatlábainak alakulásával, mint a rögzített árfolyamot alkalmazó országoké (Rey [2016] 7. o.).

Ad 3. Azokban az országokban, amelyek az 1980-as évek végétől készültek az egységes európai valuta létrehozására, már hosszú ideje nem voltak lebegetetett egymás közötti árfolyamok, és nem is nagyon jutott senkinek eszébe az, hogy olyanok lehetnének. Az optimális valutaövezetek iránti érdeklödés megújuló élénkülése kezdetén, amikor - mint fent már utaltunk rá - neves amerikai közgazdászok erre az elméletre hivatkozva bírálták a GMU tervét, az Egyesült Államokban velük szemben - Mundell [1997]-en kívül - egyedül Kenen [1998] mondott pozitív véleményt a nagy európai vállalkozásról. Kenen megszólalásának azért volt nagy jelentősége, mert egyrészt neki - kollégái nagyobb részétől eltérően - szakterülete volt a nemzetközi pénzügyek és a makroökonómia, másrészt elég alaposan ismerte az európai gazdaságot. Próbálta lebeszélni kollégáit téves ítéleteikről. Azt persze ő is pontosan látta, hogy

„Európa nem optimális valutaövezet; a bérek ott kevéssé rugalmasak, a munkaerő kevéssé mozog a határokon keresztül [1998-ban - S. K. A.], és nincs olyan költségvetési mechanizmus, amely rendszerszerüen biztosítaná pénzeszközök átcsoportosítását aszimmetrikus sokkok következményeinek kezelésére. Ráadásul nehéz elképzelni, hogy maga a GMU az európai kormányokat arra fogja késztetni, hogy kiküszöböljék ezeket a hiányosságokat." (Kenen [1998] 7. o.)

Az optimális valutaövezetek elmélete azonban

„valójában a lebegtetett és a rögzített valutaárfolyam közötti választásra vonatkozik, és itt nem arról a választásról van szó” (uo.).

Az eurót bevezető országok túl szorosan integrálódtak ahhoz, hogy eltürjék a lebegtetett árfolyamok ingadozásának mellékhatásait. Ezek az országok csak az akkor müködö Európai Monetáris Rendszer (EMS) kvázirögzített és a GMU visszavonhatatlanul rögzített árfolyamai (egységes pénze) között választhattak - hangsúlyozta Kenen.

A kvázirögzítés kvázi oldalának negatívumáról - arról, hogy a rögzítés változtathatósága a káros inflációs hullámokba való belefeledkezés melegágya - már szóltunk. Kenen a kvázirögzítés másik oldalának, a (mégiscsak) rögzítésnek a negatívumára mutatott rá. A rögzített árfolyamokkal (és a csupán kvázirögzítettekkel is) csak egyetlen monetáris politika érvényesülhetett az egész közösségben. Ez gyakorlatilag a német Bundesbank politikája volt, itt alapvetően Németország játszotta a „bázisország” szerepét, éspedig jóval erősebben, nyilvánvalóbban, mint ahogy ezt játszotta az Egyesült Államok a világgazdaság széles területein. Ez pedig sem gazdasági, sem politikai szempontból nem volt igazán elfogadható a többi tagállam számára. ${ }^{10}$ Az Európai Központi

\footnotetext{
${ }^{10}$ A Bundesbank mint az Európai Monetáris Rendszer „tényleges központi bankja” típusú rendszer sajátos szerencsétlen közgazdasági vonásait később Kenen [2003] alaposabban elemezte.
} 
Bank (és persze az ehhez tartozó közös valuta) kellett ahhoz, hogy az egyetlen monetáris politika közös monetáris politika legyen (Kenen [1998] 7. o.).

Kenen ezzel a fejtegetésével az EU vezető szerveinek a GMU elindításáról szóló döntését fogadta el. A mi elemzésünk szempontjából ebben az elfogadásban két dolog érdekes. Egyrészt az, hogy a szerzö - annak megemlítése mellett, hogy a döntésben politikai megfontolások is szerepet játszottak - rámutatott arra, hogy a döntést részben közgazdasági megfontolás is igazolta.

Másrészt, ami még inkább fontos számunkra, hogy a kérdéses közgazdasági megfontolás - a fenti 1. és 2. pontokban előadottakhoz hasonlóan - eltérő természetü azoktól a tételektől, amelyeket az előbbiekben az optimális valutaövezet elméletének elemeiként tárgyaltunk. Azok a tételek ugyanis (csak) azt mondják, hogy bizonyos feltételek fennállása mellett lehet a valutaárfolyamokat rögzíteni (természetesen azért sugallva azt, hogy a rögzítésnek lesznek kedvező következményei). Itt viszont arról van szó, hogy a fejlett piacgazdaságú országok gazdaságában a 20-21. század fordulója körül olyan problémák, zavarok mutatkoztak, amelyeket csak az árfolyamok (visszavonhatatlan) rögzítésével lehetett megszüntetni. Természetesen az ilyen rögzítés - a kérdéses zavarok ellenére - komolyan fel sem merült az Egyesült Államok, Kanada, Japán stb. esetében. Az Európai Unióban azonban az ilyen rögzítés majdnem kényszerűség volt. Alternatívája, a változtatható rögzítés a hosszas alkalmazás folyamán nagyon rossznak bizonyult.

Azt mondhatjuk, hogy a Buitertől, Mundelltól, Reytől és Kenentől itt idézettek megadják egy, a fent leírt optimálisvalutaövezet-elmélettől - amelyet itt már hagyományos elméletnek neveztük - eltérö új elmélet alapjait. Első alapvetése Mundell [1961] hagyományos elméletet is megalapozó cikkéből származik, és Mundell néhány későbbi írását is tekinthetjük úgy, mint amely hozzájárult az új elmélethez. ${ }^{11}$

Az új elmélet lényegét abban foglalhatjuk össze, hogy a piacgazdaságok közötti szoros integráció - amennyiben a tőkemozgást liberalizálták, és amennyiben az integráció a javak és szolgáltatások kereskedelmén kívül valamilyen nem nagyon kicsi mértékben a tőke- és hitelpiacokra is kiterjed - olyan problémák, zavarok forrásává válik, amelyeket ugyan nem lehetetlen kezelni, korlátok között tartani, de amelyeket (az általuk okozott károkkal együtt) csak a valutaárfolyamok (visszavonhatatlan) rögzítésével lehet megszüntetni.

Az elméletet eddig senki sem nevezte új (vagy 2.) optimálisvalutaövezetelméletnek, egyáltalán semmilyen elnevezést sem ragasztottak rá - annak ellenére, hogy fontossága, talán mondhatjuk azt is, hogy a hagyományos (vagy 1.) optimálisvalutaövezet-elmélettel való egyenrangúsága alapján alighanem megérdemli azt, hogy legyen neve. Nem adott neki nevet McKinnon [2004] sem, noha ennek az írásnak a lényege éppen a hagyományos és az új elmélet szembeállítása volt (közelebbről: Mundell [1961] mint a hagyományos, 1. és Mundell [1973a] mint az új, 2. elmélet szembeállítása egymással). Nem talált ki terminust a két elmélet egy újabb, ezúttal hazai szembeállítója (Szijártó [2017]) sem. És nem tartottak ilyesmit szükségesnek az euróövezet létrehozói sem, noha a Kenentől már a korábbiakban

\footnotetext{
${ }^{11}$ Lásd korábban az 1264. oldal apró betűs részét.
} 
idézettek szerint lényegében ennek az elméletnek a szellemében jártak el. Igaz, ők akkoriban beszéltek a hagyományos (1.) elmélet értelmében optimális valutaövezetről, de az minden érdekelt számára világos volt, hogy annak kritériumait a 11 létrehozó ország együttese nem teljesítette (vita csupán arról volt, hogy a 11-ből csak öt vagy egy-kettővel több teljesítette - De Grauwe [1997]). Azután Görögországtól Lettországig nyolc további ország csatlakozott az euróövezethez. A hagyományos (1.) elmélet kritériumai mindegyik esetben szóba kerültek, de a döntéseket a maastrichti szerződésben elöírt, jól ismert öt kritérium alapján hozták, amelyek közül egyik sem kapcsolódik az 1. elmélethez, viszont kettő - a kamatlábakra és az árfolyam-stabilitásra vonatkozó szabály - nagyon is összefügg a pénzügyi integrációval, amely az új, a 2. elmélet alapját jelenti.

A két elmélet kapcsolatában fontos terület az aszimmetrikus sokkok jövedelmeket érintő következményeinek az a korábban (a hagyományos elméletet tárgyaló fejezetben) már tárgyalt simítása, amely a hitel- és tőkepiacok határokat átszelö integráltságából fakad. Ez - mint láttuk - jól működik az Egyesült Államokban, de egyelöre (a pénzügyi integráció viszonylag alacsony szintje miatt) gyengén az euróövezetben. Meg kell említeni azonban a fordított irányú hatást is. Nyilvánvaló például, hogy külföldi államkötvények, vállalati részvények vásárlását könnyebbé, elfogadottabbá teszi az, ha ahhoz nem kapcsolódik valutaárfolyamkockázat, tehát a monetáris integráció ösztönzi a pénzügyi integrációt, és ez az euróövezetben meg is figyelhető. ${ }^{12}$

A simításproblémának ez a tárgyalása egy speciális területen tükrözi az általános tendenciát. Az utóbbi abban áll, hogy a 2. elmélet megjelenése lényegesen csökkentette az 1. elmélet szerepét, de nem szüntette meg azt, sem a gyakorlatban, sem az elméletben. Például épp a nem optimális valutaövezeten megteremtett eurót védelmezö Kenen továbbra sem adta fel azt a - mint láttuk, tőle származó - tételt, hogy az euróövezetnek szüksége van valamilyen közös költségvetésre (Kenen [2003], Eichengreen-Wyplosz [2012]). Egy másik példa: Buiter, aki az 1. elmélet talán legkeményebb kritikusa, ${ }^{13}$ az euróövezethez való brit csatlakozás lehetséges hátrányos következményeinek mérlegelésébe azért mégiscsak bevonta az aszimmetrikus keresleti sokkok problémáját (Buiter [2000] 18-21. o.), egy, néhány arab ország közös valutájának megteremtésére irányuló kezdeményezés egyik fő gyengeségét pedig abban látta, hogy ezek kevéssé kereskednek egymással (Buiter [2007] 1. o.).

\footnotetext{
${ }^{12}$ A pénzügyi integráció euróövezet-beli alakulását jellemző adatok az EKB honlapján a https:// www.ecb.europa.eu/stats/financial_markets_and_interest_rates/financial_integration/html/index. en.html címen találhatók. A témáról szóló tanulmányok egy régebbi példája $E C B$ [2007], egy újabb $E C B$ [2020a] (lásd még ECB [2020b]). A tagállamok közötti pénzügyi integráció korábban csigalassúságú fejlődése az 1990-es évek közepén a monetáris unió közeledésével felgyorsult, és tovább gyorsult az euró bevezetésével. 2008-tól a válság némileg visszavetette a fejlődést, amely 2013-tól ismét elindult. A Covid-19-válság ugyancsak visszafejlődést okozott - de a 2008-asnál kisebb mértéküt.

${ }^{13}$ Buiter szerint az optimális valutaövezetek elmélete „sajnos a második világháború utáni monetáris közgazdaságtan egyik mélypontja" (Buiter [2000] 11. o.).
} 


\section{Összefoglalás és következtetések}

Az optimális valutaövezetekre vonatkozó két elmélet közül az első - fontos előzmények után - Mundell, McKinnon, Fleming és Kenen gondolataiból adódott össze. Lényegét két fö tételben határozhatjuk meg. Az egyik szerint két vagy több ország akkor léphet egymással monetáris unióra, ha nem fenyegeti öket aszimmetrikus sokkok veszélye. Aszimmetrikus sokk lehet az egyik ország termékeit/szolgáltatásait érintő keresletcsökkenés, amely a gazdaságok szerkezetének jelentős különbségeiből adódhat (kivéve, ha erősen diverzifikált szerkezetekről van szó, mert akkor a sokkok nagy valószínűséggel kiegyenlítik egymást). Aszimmetrikus sokkok (vagy következményeik) sorozatát alkotja az inflációs ráták tartós különbsége is. Az elmélet másik fő tétele az, hogy az aszimmetrikus sokkok következményeinek kezeléséhez szükség van szabad munkaerőmozgásra és/vagy költségvetési integrációra az országok között. Az optimális valutaövezetek első elmélete (főleg a Mundellen kívüli szerzők megfogalmazásaiban) inkább negatív hangzású: azt hangsúlyozza, hogy ha a sok-sok feltétel nem teljesül, akkor inkább ne vállaljunk közös valutát. Az első elméletet tulajdonképpen azzal is jellemezhetjük, hogy az minden olyan körülményt figyelembe vesz, amely fontos lehet a monetáris integráció elfogadhatóságának szempontjából, kivéve egyet: a nemzetközi pénzügyi integrációt.

Az első mellett a második elmélet is Mundell [1961] cikkében - annak néhány, az irodalomban sohasem idézett mondatában - született, és jóval későbbi továbbfejlesztői közül magán Mundellen és a már említett Kenenen kívül érdemes kiemelni Willem Buitert. Az elmélet a nemzetközi pénzügyi integráció és a közös valuta kapcsolatáról szól. Az óvatos első elmélettel szemben inkább pozitív kicsengésü: inkább a monetáris unió elfogadására sarkall. Azt hangsúlyozza, hogy a rugalmas (lebegö) árfolyam már csekély mértékủ pénzügyi integráció esetén is súlyos bajokkal jár. $\mathrm{Az}$ erősödő kereskedelmi és pénzügyi integráció körülményei adottak lévén, az euróövezet megteremtői nem a közös pénz és a szabadon lebegtetett nemzeti pénzek között választottak: az utóbbi lehetőség gyakorlatilag nem állt rendelkezésükre. A kvázirögzített árfolyamoktól (az Európai Monetáris Rendszerből) visszalépni nem lehetett, a rendszer problémáit csak a monetáris integrációval - elöremeneküléssel tudták megoldani (és ezzel persze más, új problémákat kellett vállalniuk és kezelniük).

Elemzésünkből három fő következtetés adódik.

- Az európai Gazdasági és Monetáris Unió létrejöttének egyik fő tényezője az abban részt vevő tagállamok - a korábban is müködő árfolyam-mechanizmus (ERM) által is előmozdított - pénzügyi integrációja, az új elméletre alapuló nézetek, megfontolások erösödése volt. Ezek jelentőségét mutatja az is, hogy az euróövezethez való csatlakozás maastrichti kritériumai részben a pénzügyi integrációhoz kapcsolódnak.

- Természetesen a politikai megfontolások és a hagyományos (1.) elmélethez kapcsolódó közgazdasági tényezők sem voltak kevésbé fontosak a GMU megteremtéséröl szóló döntéssorozatban, és mindehhez hozzájárult a gazdaságszabályozás fontos területeinek részben viszonylag gyors (gondoljunk például a technikai, termékbiztonsági szabályokra), részben lassú (gondoljunk például a nemzeti tökepiaci 
szabályokra) közelítése, összehangolása. A szabályok egységesülés felé mozgásának tendenciája ( $\mathrm{a}$,jogharmonizációs” törekvések), a kereskedelmi kapcsolatok bővülése és ezzel a hagyományos elmélet kritériumainak teljesülése (jobb teljesülése) felé való mozgás és a pénzügyi integráció fejlődése az EU euróövezeten kívüli tagországait is az eurócsatlakozás felé - és az EU szomszédait az EU-val való jogharmonizáció és az EU-tagság, valamint ugyancsak az eurócsatlakozás felé - tereli. (De persze politikai tényezők vihetnek országokat az ellenkező irányba is.)

- Az eurózónához újonnan csatlakozást latolgató országoknak az előző két pontban említett gazdasági tényezők megfontolása jelenti a leckét. A hagyományos elmélet tekintetében a legtöbbször emlegetett kibocsátási szerkezet (annak az euróövezet kibocsátási szerkezetétől való eltérése) mellett nem kevésbé fontos (vagy éppen fontosabb - Neményi-Oblath [2012]) az inflációs különbség, az inflációs hajlam. Az új elmélet tekintetében azokat a problémákat, károkat kell górcső alá venni, amelyeket a külön nemzeti valuta euróárfolyamának hektikus ingadozásai okoznak.

A világ más részein általában jóval gyöngébbek a monetáris integráció felé vivő tendenciák. Időről időre felvetődnek elképzelések például közös arab pénzről (HaseebMakdisi [2018]), az Arab-öböl országainak közös pénzéről (Buiter [2007]), latinamerikai monetáris integrációról (Hafner-Kampe [2018]) stb. Az írások szerzői maguk is látják, hogy az elképzelések megvalósíthatósága az első elmélet alapján általában kétséges, és a politikai szándékok is gyakran legalábbis bizonytalanok. Ehhez azonban hozzá tudjuk tenni azt, hogy általában pénzügyi integrációs tendenciák is kevéssé mutatkoznak az elképzelt monetáris uniók potenciális tagországai között, ezért náluk nem (vagy kevéssé) érvényesül a 2. elmélet tényezőinek monetáris egyesülést ösztönző hatása sem. De mi ne tévesszük magunkat össze velük!

\section{Hivatkozások}

Ahmed, S.-Akinci, O.-Queralto, A. [2021]: U.S. Monetary Policy Spillovers to Emerging Markets: Both Shocks and Vulnerabilities Matter. Federal Reserve Bank of New York Staff Reports, No. 972. https://www.newyorkfed.org/medialibrary/media/research/staff_ reports/sr972.pdf.

Asdrubali, P.-Sørensen, B. E.-Yosha, O. [1996]: Channels of Interstate Risk Sharing: US 1963-1990. Quarterly Journal of Economics, Vol. 111. No. 4. 1081-1110. o. https://doi. org/10.2307/2946708.

AtKeson, A.-BAyoumi, T. [1993]: Do private capital markets insure regional risk? Evidence from the US and Europe. Open Economies Review, Vol. 4. No. 3. 303-324. o. https://doi. org/10.1007/BF01000047.

Bayoumi, T.-Eichengreen, B. [1997]: Ever closer to heaven? An optimum-currency-area index for European countries. European Economic Review, Vol. 41. No. 3-5. 761-770. o. https://doi.org/10.1016/S0014-2921(97)00035-4.

Begg, D.-Eichengreen, B.-Halpern, L.-von Hagen, J.-Wyplosz, C. [2003]: Sustainable Regimes of Capital Movements in Accession Countries. CEPR Policy Paper, No. 10. https:// cepr.org/sites/default/files/geneva_reports/GenevaPP10.pdf. 
Benczes István [2014]: The theory of optimum currency areas. Megjelent: Palánkai Tibor (szerk.): Economics of global and regional integration. Akadémiai Kiadó, Budapest, 83-95. o.

Bod Péter Ákos-Pócsik Orsolya-Neszmélyi György Iván [2020]: Az euró és a szlovák gazdaság. Közgazdasági Szemle, 67. évf. 4. sz. 321-351. o. http://dx.doi.org/10.18414/ Ksz.2020.4.321.

Boughton, J. M. [2003]: On the Origins of the Fleming-Mundell Model. IMF Staff Papers, Vol. 50. No. 1. 1-3. o. https://doi.org/10.5089/9781451852998.001.

Buiter, W. H. [2000]: Optimal Currency Areas: Why Does the Exchange Rate Regime Matter? With an Application to UK Membership in EMU. Centre for Economic Performance, LSE, London.

Buiter, W. H. [2007]: Economic, Political, and Institutional Prerequisites for Monetary Union among the Members of the Gulf Cooperation Council. Economies Review, Vol. 19. No. 5. 579-612. o. https://doi.org/10.1007/s11079-008-9081-9.

CAlmfors, L. [2001]: Unemployment, Labour Market Reform, and Monetary Union. Journal of Labour Economics, Vol 19. No. 3. 265-289. o.

Capie, F. [1998]: Monetary Unions in Historical Perspective: What Future for the Euro in the International Financial System. Megjelent: Fratianni, M.-Salvatore, D.-Savona, P. (szerk.): Ideas for the Future of the International Monetary System. Springer, Boston, MA. https:// doi.org/10.1007/978-1-4757-5450-6_4.

Cesarano, F. [2006]: The Origins of the Theory of Optimum Currency Areas. History of Political Economy, Vol. 38. No. 4. 711-731. o. https://doi.org/10.1215/00182702-2006-017.

Corden, W. M. [1972]: Monetary Integration. Essays in International Finance, No. 93. Princeton University Press, Princeton.

Dautovic, E.-Orszaghova, L.-Schudel, W. [2014]: Intra-Industry Trade between CESEE Countries and the EU15. ECB Working Paper, No. 1719. European Central Bank, Frankfurt/M.

De Grauwe, P. [1997]: The Economics of Monetary Integration. Oxford University Press, Oxford.

De Grauwe, P. [2003]: The Challenge of Enlargement of Euroland. Workshop on EMU: Current State and Future Prospects. University of Crete, Rethymno, augusztus 24-31.

De Grauwe, P. [2006]: What have we learnt about monetary integration since the Maastricht Treaty? Universita degli Studi di Macerata Dipartimento di Studi sullo Sviluppo Economico, Working Paper, No. 3. https://core.ac.uk/download/pdf/7067247.pdf.

Dellas, H.-Tavlas, G. H. [2009]: An optimum-currency-area odyssey. Journal of International Money and Finance, Vol. 28. No. 7. 1117-1137. o. https://doi.org/10.1016/j.jimonfin. 2009.06.001.

Diaz SANCHEZ, J. L.-VAROudAKis, A. [2013]: Growth and competitiveness as factors of Eurozone external imbalances: Evidence and policy implications. World Bank, Washington, DC. Policy Research Working Paper, No. 6732. https://doi.org/10.1596/1813-9450-6732.

Diaz SANCHEZ, J. L.-VAROUdAKIS, A. [2016]: Tracking the causes of Eurozone external imbalances: New evidence and some policy implications. International Economics and Economic Policy, Vol. 13. No. 4. 641-688. o. https://doi.org/10.1007/s10368-015-0316-0.

Draghi, M. [2012]: Speech by Mario Draghi, President of the European Central Bank at the Global Investment Conference in London 26 July 2012. European Central Bank, https:// www.ecb.europa.eu/press/key/date/2012/html/sp120726.en.html.

ECB [2007]: Financial Integration in Europe, March 2007. European Central Bank, Frankfurt/M. https://www.ecb.europa.eu/pub/pdf/fie/financialintegrationineurope200703en.pdf. 
ECB [2020a]: Financial Integration and Structure in the Euro Area, March 2020. European Central Bank, Frankfurt/M. https://www.ecb.europa.eu/pub/pdf/fie/ecb.fie2020 03 197074785e.en.pdf.

ECB [2020b]: European financial integration during the COVID-19 crisis. ECB Economic Bulletin, No. 7/2020. https://www.ecb.europa.eu/pub/economic-bulletin/articles/2020/ html/ecb.ebart202007_02 b27e8089c5.en.html.

Eichengreen, B. [2019]: Globalizing Capital. A History of the International Monetary System. Princeton University Press, Princeton.

Eichengreen, B.-Wyplosz, C. [2012]: Kenen on the euro. VoxEU/CEPR, London, december 12. https://voxeu.org/article/kenen-euro.

ET [2021]: Az európai helyreállítási terv. Elfogadták a Helyreállítási és Rezilienciaépítési Eszközről szóló rendeletet. Európai Tanács, február 11. https://www.consilium.europa.eu/hu/ policies/eu-recovery-plan/.

Fabiani, J.-Fidora, M.-Setzer, R.-Westphal, A.-Zorell, N. [2021]: Sudden Stops and Asset Purchase Programmes in the Euro Area. ECB Working Paper, No. 2597. https://www. ecb.europa.eu/pub/pdf/scpwps/ecb.wp2597 03358dce12.en.pdf.

FIDRMUC, J. [2001]: The Endogeneity of the Optimum Currency Area Criteria, Intraindustry Trade, and Emu Enlargement. BOFIT Discussion Papers, 8/2001. Bofit, Helsinki.

Fleming, J. M. [1962]: Domestic financial policies under fixed and floating exchange rates. IMF Economic Review, Vol. 9. 369-379. o. https://doi.org/10.2307/3866091.

Fleming, J. M. [1971]: On Exchange Rate Unification. The Economic Journal, Vol. 81. No. 323. 467-488. o. https://doi-org.eres.qnl.qa/10.2307/2229844.

Frankel, J. A.-Rose, A. K. [1998]: The Endogeneity of the Optimum Currency Area Criteria. The Economic Journal, Vol. 108. No. 449. 1009-1025. o. https://doi.org/10.1111/14680297.00327.

Friedman, M. [1953a]: The Case for Flexible Exchange Rates. Megjelent: Friedman, M.: Essays in Positive Economics. University of Chicago Press, Chicago, 157-203. o.

Friedman, M. [1953b]: Living with the Dollar. The Economist, No. 166. 16. o.

Friedman, M. [1973]: Contemporary Monetary Problems. Economic Notes, Vol. 2. No. 1. 5-18. o.

Friedman, M. [1989]: The Case for Floating Exchange Rates. Financial Times, december 18. https://miltonfriedman.hoover.org/friedman_images/Collections/2016c21/ FTL_12_18_1989.pdf.

Friedman, M. [1997]: The Euro: Monetary Unity to Political Disunity? Project Syndicate, augusztus 27. https://www.project-syndicate.org/commentary/the-euro--monetary-unityto-political-disunity.

Goetz, M. R.-Gozzi, J. C. [2020]: Financial Integration and the Co-Movement of Economic Activity: Evidence from U.S. States. Board of Governors of the Federal Reserve System. International Finance Discussion Papers, No. 1305.

Gourinchas, P.-O.-Rey, H.-SAuzet, M. [2019]: The International Monetary and Financial System. Annual Review of Economics, Vol. 11. No. 1. 859-893. o. https:/doi.org/10.1146/ annurev-economics-080217-053518.

Haberler, G. [2015]: The International Monetary System: Some Recent Developments and Discussions. Megjelent: Bergsten, C. F.-Halm, G. N. [2015]: Approaches to Greater Flexibility of Exchange Rates. Princeton University Press, Princeton, 115-124. o.

Hafner, K. A.-Kampe, L. [2018]: Monetary union in Latin America: an assessment in the context of optimum currency area. Applied Economics, Vol. 50. No. 52. 5672-5697. o. https://doi.org/10.1080/00036846.2018.1489116. 
Hall, P. A.-Soskice, D. (szerk.) [2001]: Varieties of Capitalism: The Institutional Foundations of Comparative Advantage. Oxford University Press, Oxford.

HARTLAND, P. [1949]: Interregional Payments Compared with International Payments. Quarterly Journal of Economics, Vol. 63. No. 3. 392-407. o. https://doi.org/10.2307/1882262.

Haseeb, K. E.-D.-Makdisi, S. (szerk.) [2018]: Arab Monetary Integration. Issues and Prerequisites. Routledge, London.

Helliwell, J. [1998]: How Much Do National Borders Matter? Brookings, Washington, DC. Hoffmann, M.-Sørensen, B. [2012]: Don't expect too much from EZ fiscal union - and complete the unfinished integration of European capital markets! VoxEU/CEPR, https://voxeu. org/article/hedging-macroeconomic-risk-eurozone-fiscal-union-versus-capital-markets.

Höpner, M.-LutTer, M. [2014]: One Currency and Many Modes of Wage Formation. Why the Eurozone Is Too Heterogeneous for the Euro. Max Planck Institute for the Study of Societies, Köln, MPIfG Discussion Paper, 14/14. https://doi.org/10.13140/RG.2.2.33033.85605.

INGRAM, J. C. [1973]: The Case for the European Monetary Integration. Princeton University, Essays in International Finance, No. 98. https://ies.princeton.edu/pdf/E98.pdf.

Kenen, P. B. [1969]: The theory of optimum currency areas. An eclectic view. Megjelent: Mundell, R. A.-Swoboda, A. K. (szerk.): Monetary Problems of the International Economy. University of Chicago Press, Chicago, 41-60. o.

KENEN, P. B. [1998]: EMU and Transatlantic Economic Relations. HWWA-Diskussionspapier 60. HWWA-Institut für Wirtschaftsforschung, Hamburg, https://d-nb.info/1196355851/34.

Kenen, P. B. [2003]: Five Years of the ECB. CentrePiece 2003. nyár, https://cep.lse.ac.uk/pubs/ download/CP147.pdf.

KirkegaARD, J. F.-Posen, A. F. (szerk.) [2018]: Lessons for EU Integration from US History. Report to the European Commission. Peterson Institute for International Economics, Washington, DC. https://piie.com/system/files/documents/kirkegaard-posen_ecreport2018-01.pdf.

KLaus, V. [2004]: The Future of the Euro: an Outsider's View. Cato Journal, Vol. 24. No. 1-2. 171-177. o. https://www.cato.org/sites/cato.org/files/serials/files/cato-journal/2004/5/ cj24n1-2-16.pdf.

Krekó Judit-Oblath Gábor [2020]: Economic growth and real exchange rate misalignments in the European Union. Acta Oeconomica, Vol. 70. No. 3. 297-332. o. http://doi. org/10.1556/032.2020.00016.

Krugman, P. [1991/2003]: Földrajz és kereskedelem. Nemzeti Tankönyvkiadó, Budapest.

LERner, A. R. [1944]: The Economics of Control: Principles of Welfare Economics. Macmillan, New York.

Losoncz MikLós [2019]: A gazdasági és monetáris unió fenntarthatóságának néhány kérdése. Közgazdasági Szemle, 66. évf. 5. sz. 478-496. o. https://doi.org/10.18414/KSZ.2019.5.478.

McCallum, J. [1995]: National Borders Matter: Canada-US Regional Trade Patterns. American Economic Review, Vol. 85. No. 3. 615-623. o.

McKinnon, R. I. [1963]: Optimum Currency Areas. The American Economic Review, Vol. 53. No. 4. 717-725. o.

McKinnon, R. I. [1969[: Comment. Megjelent: Mundell, R. A.-Swoboda, A. K. (szerk.): Monetary Problems of the International Economy. University of Chicago Press, ChicagoLondon.

McKinnon, R. I. [2004]: Optimum Currency Areas and Key Currencies. Mundell I versus Mundell II. Journal of Common Market Studies, Vol. 42. No. 4. 689-715. o. https://doi. org/10.1111/j.0021-9886.2004.00525.x. 
Minaljek, D.-Klau, M. [2003]: The Balassa-Samuelson effect in central Europe: a disaggregated analysis. BIS Working Papers, No. 143. https://www.bis.org/publ/work143.pdf.

Mill, J. S. [1894]: Principles of Political Economy. Vol. II. Routledge, New York.

MolendowsKi, E. [2014]: The Visegrad Group Countries - changes in intra-industry competitiveness of their economies during the world financial and economic crisis. Procedia Social and Behavioral Sciences, Vol. 110. 1006-1013. o. https:/www.sciencedirect.com/ search?authors=MOLENDOWSKI.

Mongelli, F. P. [2008]: European Economic and Monetary Integration, and the Optimum Currency Area Theory. European Economy, Economic Papers, No. 302. https://ec.europa. eu/economy_finance/publications/pages/publication12081_en.pdf.

Mundell, R. A. [1960]: The Monetary Dynamics of International Adjustment under Fixed and Flexible Exchange Rates. The Quarterly Journal of Economics, Vol. 74. No. 2. 227-257. o. https://doi.org/10.2307/1884252.

Mundell, R. A. [1961]: A Theory of Optimum Currency Areas. The American Economic Review, Vol. 51. No. 4.657-665. o.

Mundell, R. A. [1963]: Capital mobility and stabilization policy under fixed and flexible exchange rates. Canadian Journal of Economics and Political Science, Vol. 29. No. 4. 475-485. o. https://doi.org/10.2307/139336.

Mundell, R. A. [1973a]: Uncommon Arguments for Common Currencies. Megjelent: Johnson, H.-Swoboda, A. K. (szerk.): The Economics of Common Currencies. Harvard University Press, Cambridge, 114-132. o.

Mundell, R. A. [1973b]: „A Plan for European Currency.” Megjelent: Johnson, H.-Swoboda, A. K. (szerk.): The Economics of Common Currencies. Harvard University Press, Cambridge, 143-171. o.

Mundell, R. A. [1997]: Updating the Agenda for Monetary Union. An extended version of a luncheon speech presented at the December 1996 Tel Aviv conference on optimum currency areas. Megjelent: Blejer, M. I.-Frenkel, J. A.-Leiderman, L.-Razin, A.-Cheney, D. M. (szerk.): Optimum Currency Areas. New Analytical and Policy Developments. IMF, Washington.

Mundell, R. A. [1999]: A Reconsideration of the Twentieth Century. Prize Lecture, december 8. Department of Economics, Columbia University, New York.

Müller, P.-Pauly, C.-Reiermann, C. [2011]: ECB Chief Economist Quits. Jürgen Stark's Resignation Is Setback for Merkel. Spiegel International, szeptember 12. https:// www.spiegel.de/international/europe/ecb-chief-economist-quits-juergen-stark-sresignation-is-setback-for-merkel-a-785668.html.

NemÉNy Judit-OBLATH GÁBOR [2012]: Az euró bevezetésének újragondolása. Közgazdasági Szemle, 59. évf. 6. sz. 569-684. o.

Pichelmann, K. [2003]: Wage Developments in the early years of EMU. Megjelent: Fagan, G.Mongelli, F. P.-Morgan, J. (szerk.): Institutions and Wage Formation in the New Europe. Edwar Elgar, London, 98-111. o.

PolánYi KÁROLY [2004]: A nagy átalakulás. Korunk gazdasági és politikai gyökerei. Napvilág Kiadó, Budapest.

Rey, H. [2016]: International Channels of Transmission of Monetary Policy and the Mundellian Trilemma. IMF Economic Review, Vol. 64. No. 1. 6-35. o. https://doi.org/10.1057/ imfer.2016.4. 
Rose, A. K. [2008]: EMU, Trade and Business Cycle Synchronization: What Do We Know and What Does It Mean for Poland? Narodowy Bank Polski, Varsó, 279-297. o. https://ssl. nbp.pl/konferencje/bise_2008/rosep.pdf.

SAndBu, M. [2015]: Europe's Orphan. The Future of the Euro and the Politics of Debt. Princeton University Press, Princeton.

Schiffman, D.-Young, W.-Zelekha, Y. [2018]: Politicization of Policy Prescriptions: Friedman and Israeli Economic Reform, 1977. Megjelent: Schiffman, D.-Young, W.-Zelekha, Y.: The Role of Economic Advisers in Israel's Economic Policy. Springer, Cham, 81-123. o. https://doi.org/10.1007/978-3-319-60682-8_5.

Sinn, H.-W. [2018]: The ECB’s Fiscal Policy. NBER Working Paper, No. 24613. https://www. nber.org/system/files/working_papers/w24613/w24613.pdf.

Soós Károly Attila [2019]: Az eurózóna a válság után: fiskális unió nélkül is müködőképes monetáris unió. Külgazdaság, 63. évf. 9-10. sz. 3-38. o. https://doi.org/10.47630/ KULG.2019.63.9-10.3.

SzIJÁrtó Norbert [2017]: Az optimális valutaövezetek elmélet fejlődése. Köz-Gazdaság, 12. évf. 3. sz. 129-148. o. http://real.mtak.hu/80702/1/Koz_Gazdasag_2017_3_Szijarto_ Norbert_u.pdf. 